\title{
Reproductive activity and biochemical composition of the pullet carpet shell Venerupis senegalensis (Gmelin, 1791) (Mollusca: Bivalvia) from Ria de Aveiro (northwestern coast of Portugal)
}

\author{
SANDRA JOAQUIM ${ }^{1}$, DOMITÍLIA MATIAS ${ }^{1}$, ANA MARGARETE MATIAS ${ }^{1}$, \\ PAULA MOURA $^{1}$, WILLIAM S. ARNOLD ${ }^{2}$, LUIIS CHÍCHARO ${ }^{3}$ \\ and MIGUEL BAPTISTA GASPAR ${ }^{1}$ \\ ${ }^{1}$ Instituto Nacional de Recursos Biológicos, L-IPIMAR, Av. 5 de Outubro s/n, 8700305 Olhão, Portugal. \\ E-mail: sandra@ipimar.pt \\ ${ }^{2}$ NOAA/NMFS Southeast Regional Office, 263 13th Avenue South St. Petersburg, FL 33701, U.S.A. \\ ${ }^{3}$ Universidade do Algarve, Centro de Ciências do Mar (CCMAR), Campus de Gambelas, P-8005-139 Faro, Portugal.
}

\begin{abstract}
SUMMARY: The present study characterizes the reproductive cycle of Venerupis senegalensis (=V. pullastra) from Ria de Aveiro (Portugal) as well as its nutrient storage and exploitation strategy. The reproductive cycle followed a seasonal cycle that correlated negatively with sea surface temperature, and comprised a ripe stage in winter followed by a spawning period that began in late winter and ended in the early summer. This extended spawning may be an advantageous strategy for the species because it ensures a continuous supply of settlers. Gametogenesis began in late summer/early autumn and intensified with the decrease in temperature during autumn. The condition index increased even during the spawning period, which indicates that there is rapid recovery and that reserves are accumulated during late summer and used later in the gametogenic process. Proteins did not contribute significantly to gametogenesis and the glycogen pattern is typical of conservative species, since gametogenesis depends largely on the amount of glycogen stored. The lipid storage and utilization cycle showed that gametogenesis took place in autumn/winter and that energy reserves were accumulated in summer.
\end{abstract}

Keywords: pullet carpet shell, Venerupis senegalensis, biochemical composition, condition index, reproductive cycle.

RESUMEN: ACTIVIDAD REPRODUCTIVA Y COMPOSICIÓN BIOQUímiCA DE LA ALMEJA BABOSA VENERUPIS SENEGALENSIS (GMELIN, i79i) (Mollusca: Bivalvia) de la Ría de Aveiro (Costa noroeste de Portugal). - El presente estudio caracteriza el ciclo reproductivo de Venerupis senegalensis (= V. pullastra) en la Ría de Aveiro (Portugal) así como su estrategia de almacenamiento y explotación de los nutrientes. El ciclo reproductivo de esta especie sigue un ciclo estacional que se correlaciona negativamente con la temperatura del agua del mar, que coincide con un estado de madurez en el invierno, seguido de un periodo de desove que se inicia a finales de invierno y termina a principios del verano. Este periodo de puesta prolongado puede ser una estrategia ventajosa para la especie, ya que garantiza un suministro continuo de larvas. La gametogénesis comenzó a finales del verano/inicios de otoño y se intensificó con la disminución de la temperatura durante el otoño. El aumento del índice de condición, todavía durante la puesta, indica una recuperación rápida y una acumulación de reservas a finales del verano, que serán utilizadas en el siguiente proceso de gametogénesis. Las proteínas no contribuyen significativamente a la gametogénesis y el ciclo de glucógeno es típico de las especies conservadoras, una vez que la gametogénesis depende, en gran medida, de la cantidad de glucógeno almacenado. El almacenamiento de lípidos y su utilización indica la gametogénesis en el otoño/invierno, así como el proceso de acumulación de energía en verano.

Palabras clave: almeja babosa, Venerupis senegalensis, composición bioquímica, índice de condición, ciclo reproductivo. 


\section{INTRODUCTION}

Venerupis senegalensis $(=V$. pullastra) is commercially exploited in Portugal, Spain, France and Italy (FAO, 2006-2010). Presently in mainland Portugal, $V$. senegalensis is most abundant in the Ria de Aveiro lagoon on the west coast, although Maia et al. (2006) reported that between 2001 and 2006 this population declined due to overfishing and recruitment failure. This species was also once abundant in the Ria Formosa lagoon; however, in the early 1980s these populations declined dramatically for the same reasons (Massapina and Arrobas, 1991). This not only threatened the sustainability of the fishery, but also compromised the productive potential of both of these important lagoonal ecosystems (Joaquim et al., 2008a). An active intervention may be necessary not only to restore stocks to reproductive viability in both Ria de Aveiro and Ria Formosa, but also to provide alternative or complementary products for the shellfish aquaculture industry. Intensive hatchery production of juveniles will therefore be necessary. However, inherent physiological variability among bivalve larvae can always be expected in production situations (Massapina et al., 1999), and understanding the source of this variability is crucial for reducing it. Broodstock condition is an important factor that contributes to this variability (Magnesen and Christophersen, 2008). The relationship between the reproductive cycle and energy storage and utilization cycles has already been reported by several authors for a wide variety of bivalves (e.g. Barber and Blake, 1981; Fernandez Castro and Vido de Mattio, 1987; Massapina et al., 1999; Pérez-Camacho et al., 2003). In general, reserves accumulate prior to gametogenesis in the form of glycogen, lipid and protein substrates, and are used in the production of gametes when metabolic demand is high (Mathieu and Lubet, 1993). Previous works have studied the reproduction of $V$. senegalensis (Villalba et al., 1993; Maia et al., 2006; Cerviño-Otero et al., 2007a) and its biochemical composition (Alvarez-Seoane, 1960; Gonzalez, 1975; Albentosa et al., 2007). Nevertheless, the reproductive cycle is influenced by local environmental conditions such as food availability and temperature (e.g. Gabbott, 1976; Pérez-Camacho et $a l ., 2003)$. Therefore, understanding the natural reproductive cycle of $V$. senegalensis is essential for establishing successful hatchery-based production. Maia et al. (2006) reported the reproductive cycle of a Ria de Aveiro population of $V$. senegalensis; however, no information on the relationship between the reproductive cycle and biochemical composition was provided.

In the present study we characterize the reproductive cycle of $V$. senegalensis from the Ria de Aveiro, including patterns of nutrient storage and utilization. This information could be useful in the future for both the aquaculture production of this species and
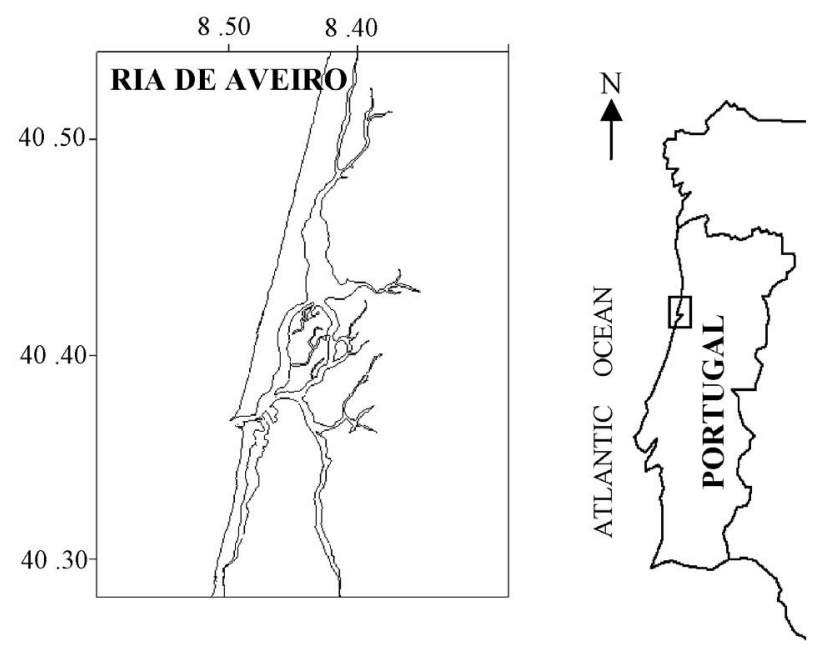

FIG. 1. - Ria de Aveiro location.

for implementing programs to enhance and restore natural stocks to reproductive viability.

\section{MATERIALS AND METHODS}

\section{Collection of samples}

Adult specimens of Venerupis senegalensis were collected fortnightly during 2006 and 2007 by local dredgers from a site in Ria de Aveiro $\left(40^{\circ} 42^{\prime} \mathrm{N}\right.$; $08^{\circ} 40^{\prime} \mathrm{W}$, western Portugal; Fig. 1) at water depths ranging from 4 to $8 \mathrm{~m}$. Monthly sea surface temperature (SST) data were measured with a YSI multiparameter probe (Model 556 MPS).

\section{Laboratory analysis}

The laboratory analyses were only performed for standard animals with a shell length ranging from 36 to $38 \mathrm{~mm}$ to avoid the influence of growth, and thus minimize bias from increasing somatic weight and focus on the accumulation or loss of organic matter associated with reproduction (Beninger and Lucas, 1984). In the laboratory, clams were placed in 0.45 $\mu \mathrm{m}$-filtered seawater at $20^{\circ} \mathrm{C}$ for $24 \mathrm{~h}$ to purge their stomachs before histological, condition index and biochemical analyses. Following the $24 \mathrm{~h}$ purging period, each clam was dissected and the wet soft tissue weight was determined on a top-loading digital balance (precision of $0.01 \mathrm{~g}$ ) after 15 minutes on a sloped plane covered with absorbent paper.

\section{Histology}

Ten males and ten females from each fortnightly sample were examined histologically to ascertain gonadal development. The visceral mass was separated from siphons and gills and fixed in San Felice solution for $24 \mathrm{~h}$, then transferred to $70 \%$ ethyl alcohol (ETOH) for storage. For microscopic examination, 
tissues from these samples were dehydrated with serial dilutions of alcohol and embedded in paraffin. Thick sections $(6-8 \mu \mathrm{m})$ were cut on a microtome and stained with haematoxylin and eosin. The histologically prepared slides were examined using a microscope at 40× magnification and each specimen was assigned to a stage which represented the gonad condition. Clam reproductive maturity was categorized into six stages using the gametogenic scale proposed by Gaspar and Monteiro (1998):

Inactive. Sexes are indistinguishable microscopically due to the total absence of follicles and gametes.

Early active. The connective tissue is abundant and the size of follicles is small. In females the oocytes are attached to the basal membrane by the stalk. In males spermatocytes proliferate toward the lumina.

Late active. Interfollicular connective tissue scarce. Follicles become larger. In females most oocytes are free in the lumina while some are still attached to the basal membrane. Appearance of sperm in the lumina, which form weak columns with tails orientated toward the centre.

Ripe. The connective tissue has been replaced by follicles that are full of ripe gametes. In females the oocyte tale is oval or polygonal shape and in males the lumina are packed with spermatozoa.

Partially spawned. The gametes are discharged. Depending on the degree of spawning the follicles are more or less empty. The follicle walls are broken. There are many empty spaces between and within the follicles.

Spent. Abundant interfollicular connective tissue. Occasional residual sperm or oocytes present.

When more than one developmental stage occurred simultaneously within a single individual, the staging criteria was based on the condition of the majority of the section. For each of the stages a numerical ranking was assigned as follows: inactive (0); early active (3); late active (4); ripe (5); partially spawned (2); spent (1). A mean gonad index (GI) was then calculated using the method proposed by Seed (1976):

$$
\mathrm{GI}=\frac{\sum \text { ind. each stage } \times \text { stage ranking }}{\text { total ind. each month }}
$$

The GI ranged from 0 (all individuals in the sample are resting) to 5 (all individuals are ripe).

\section{Condition index}

Dry soft tissues and shell weights of 20 clams from each sample were determined after oven drying at $80^{\circ} \mathrm{C}$ for $24 \mathrm{~h}$. Soft tissue samples were then ashed at $450^{\circ} \mathrm{C}$ in a muffle furnace, the ash weight was determined and the organic matter weight calculated as the ash-free dry soft-tissue weight (AFDW). The condition index (CI) was calculated according to Walne and Mann (1975):

$$
\mathrm{CI}=\frac{\text { ash free dry weight }(\mathrm{mg})}{\text { dry shell weight }(\mathrm{mg})} \times 100
$$

\section{Biochemical composition}

The soft tissue of five clams of each fortnightly sample was frozen and stored at $-20^{\circ} \mathrm{C}$ for biochemical analyses. For each specimen, protein was determined using the modified Lowry method (Shakir et al., 1994), glycogen content was determined from dried $\left(80^{\circ} \mathrm{C}\right.$ for $24 \mathrm{~h}$ ) homogenate using the anthrone reagent (Viles and Silverman, 1949) and total lipids were extracted from fresh homogenized material in chloroform/methanol (Folch et al., 1957) and estimated spectrophometrically after charring with concentrated sulphuric acid (Marsh and Weinstein, 1966). Duplicate determinations were performed in all cases and values were expressed as a percentage of AFDW. The caloric content of protein, lipid and carbohydrates in tissues was calculated using the factors $17.9 \mathrm{~kJ} \mathrm{~g}^{-1}$ (Beukema and De Bruin, 1979), $33 \mathrm{~kJ} \mathrm{~g}^{-1}$ (Beninger and Lucas, 1984) and $17.2 \mathrm{~kJ} \mathrm{~g}^{-1}$ (Paine, 1971) respectively.

\section{Statistics}

Significant differences in the condition index, biochemical composition and histological parameters during the study period were tested using one-way ANOVA. Whenever the assumptions of analysis of variance were not met, the Kruskal-Wallis ANOVA on ranks test was performed. Prior to any analyses, percentage data were arcsine transformed to normalize variance (Sokal and Rohlf, 1981). Multiple pairwise comparisons were performed using the post-hoc parametric Tukey test or the non-parametric Dunn's test in order to detect significant differences between fortnightly consecutive samples. The Spearman correlation coefficient was used to determine the degree of association between parameters. The statistical analyses were undertaken using the SIGMASTAT 3.11 statistical package.

\section{RESULTS}

\section{Temperature}

The evolution of the monthly SST during the experimental period in Ria de Aveiro is presented in Figure 2. A seasonal cycle in SST was observed, and ranged between 11.7 in February 06 and $20.7^{\circ} \mathrm{C}$ in May 07.

\section{Gametogenic cycle}

The sexes were clearly separated and no hermaphrodites were found. Both sexes generally showed synchronism in gonadal development. The reproductive cycle of $V$. senegalensis was characterized by a sea- 


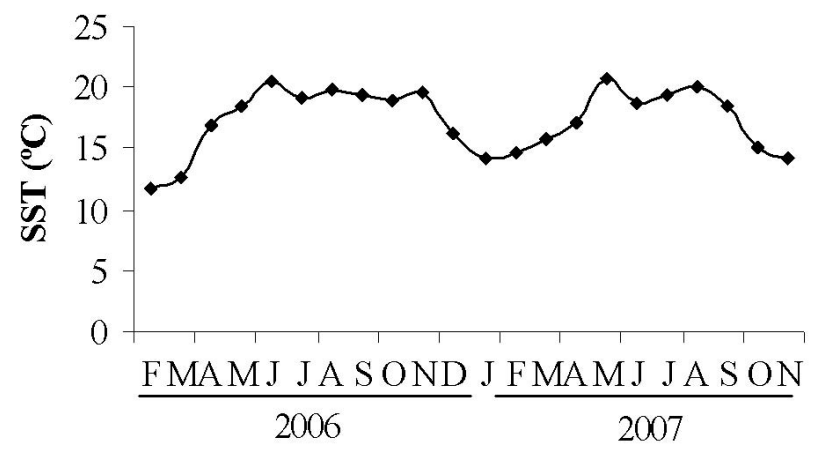

FIG. 2. - Monthly values of sea surface temperature (SST) in Ria de Aveiro from February 2006 to November 2007. sonal pattern (Fig. 3). The GI was negatively correlated with SST (Spearman's r=-0.65, $\mathrm{P}<0.001$ ) (Table 1). The onset of the gametogenic cycle occurred in October 06 and August 07; however, there was a short inactive period (the maximum sexual inactivity, 70\%, was observed in August 07). The development of gametes intensified during the autumn, which coincided with the decrease in SST. Spawning began in winter, intensified during spring as SST increased, and continued until August. However, in summer most of the population had already spawned and was inactive. Nevertheless, in spite of the seasonal pattern, $V$. senegalensis did not show continuous gonad development, in which stages would occur sequentially, especially during the spawn-

\section{Males}

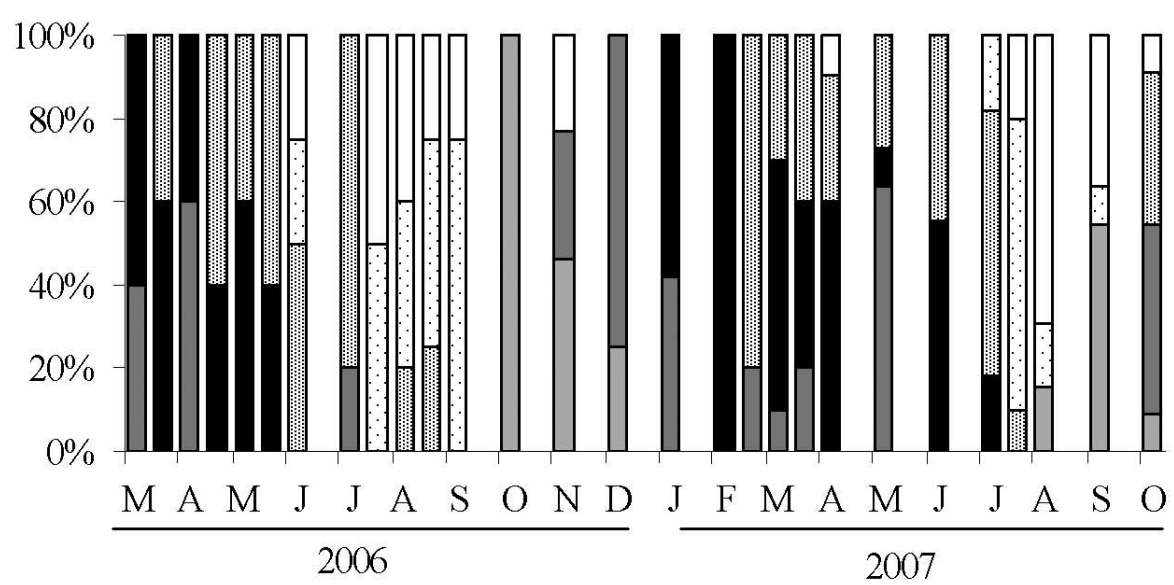

Females

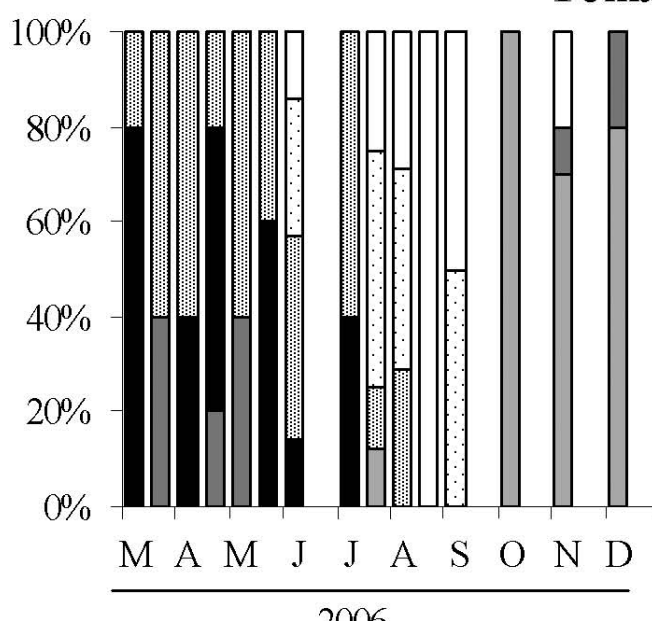

2006

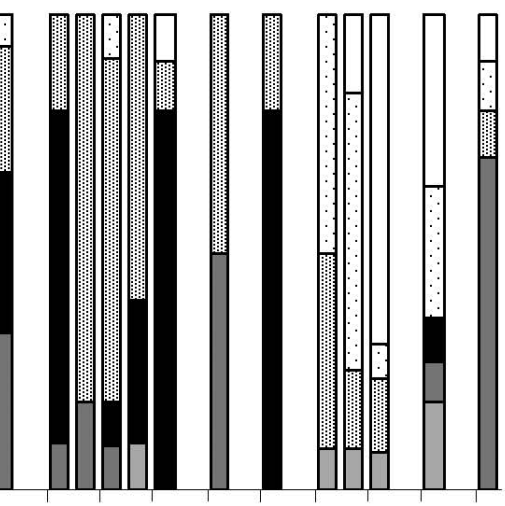

Early active

四 Partially active

$\square$ Late active

$\square$ Spend

- Ripe

$\square$ Inactive

FIG. 3. - Monthly variations in gonadal development of V. senegalensis during 2006 and 2007. Males (top) and Females (bottom).

TABLE 1. - Results of Spearman correlation between studied parameters $(r$, correlation coefficient, $P, P$ value, n.c., no correlation was found $)$

\begin{tabular}{lcccccc}
\hline & Gonad index & Condition index & Proteins & Total lipids & Glycogen & Total energy \\
\hline Temperature & $r=-0.65 P<0.001$ & $r=0.55 P=0.01$ & $r=-0.65 P<0.001$ & n.c. & n.c. & $r=-0.65 P<0.001$ \\
Gonad index & & $r=-0.65 P<0.001$ & n.c. & n.c. & $r=-0.65 P<0.001$ & n.c. \\
Condition index & & & $r=-0.74 P<0.001$ & n.c. & $r=0.71 P<0.001$ & n.c. \\
Proteins & & & n.c. & $r=0.54 P=0.01$ & $r=0.53 P=0.01$ \\
Total lipids & & & & & & n.c. \\
Glycogen & & & & & \\
\hline
\end{tabular}




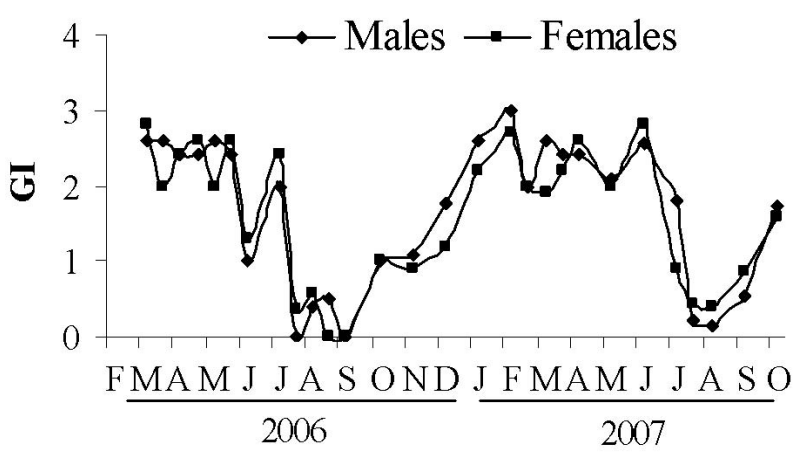

FIG. 4. - Gonad index (GI) of $V$. senegalensis during the experimental period.

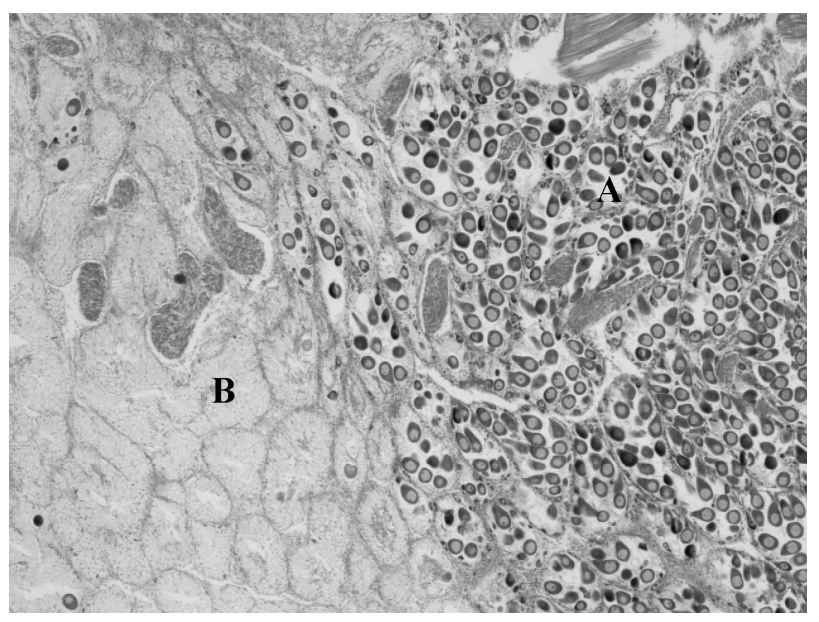

FIG. 5. - Detail of different stages of gonadal development coexisting in the same $V$. senegalensis individual. A, early/late active; B, spent.

ing period. For example, in late March 06, about 60\% of males were in the "ripe" stage whereas the remaining males were "partially spawned". In the following sample, $60 \%$ of the population restarted gametogenesis with the development of new gametes, whereas $40 \%$ of the population remained in the "ripe" stage. This phenomenon occurred in both study years and for both males and females, and can be observed in the series of alternating increases and decreases in the GI (Fig. 4) during the spawning period. Indeed, in microscopic examinations of the gonadal tissues it was common to observe different stages of gonadal development in the same individual (Fig. 5), which indicates simultaneous spawning and recovery of the gonad. The gonad index followed the same pattern as gonad development; no significant differences in GI were found between sexes (ANOVA, $\mathrm{P}=0.877$ ) or between years (ANOVA, $\mathrm{P}=0.073)$.

\section{Condition index}

The condition index showed statistically significant differences among samples (K-W., $\mathrm{H}=689.0$, d.f. $=33$, $\mathrm{P}<0.001)$ but not between years $\left(\mathrm{K}-\mathrm{W} ., \mathrm{H}=2.7\right.$, d.f. $_{\mathrm{N}}$,

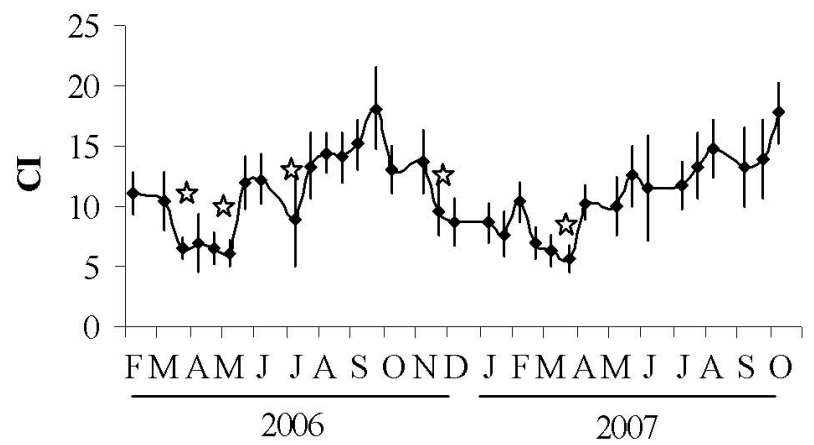

FIG. 6. - Mean condition index ( \pm S.D.) in V. senegalensis during the experimental period (* statistically significant differences, $P<0.05$ found between consecutive months).

$\mathrm{P}=0.102)$. SST was positively correlated with $\mathrm{CI}$ (Spearman's r=0.55, P=0.01). Between early February and late March, CI decreased with the beginning of spawning. After early May 06 and in May 07, this index generally trended upward until late September 06 and early October 07 respectively, which corresponded to the maximum SST. Exceptions were found between late May and early July 06 and in late August 07, when the CI decreased slightly (Fig. 6). After late September 06, the CI generally decreased until late January 07 (with the exceptions of early November 06) following the temperature trend and the increase in the mean gonad index. The highest CI value $(18.09 \pm 3.37)$ was registered in late September 06. In that month, the majority of clams (both males and females) were in the "spent" or "inactive" stage. The CI was negatively correlated with the GI (Spearman's $r=-0.65, \mathrm{P}<0.001$ ) (Table 1).

\section{Biochemical composition}

Proteins were the predominant dry tissue constituent of the clams followed by total lipids and glycogen (Table 2). The highest protein content value was recorded in early March 07 (377.8 $\pm 85.9 \mu \mathrm{g} \mathrm{mg}^{-1}$ AFDW) and the lowest in late May $06\left(142.2 \pm 48.8 \mu \mathrm{g} \mathrm{mg}^{-1}\right.$ AFDW). Protein content was inversely correlated with SST (Spearman's r=-0.65, P<0.001) and with CI (Spearman's r $=-0.74, \mathrm{P}<0.001$ ) (Table 1). Glycogen was generally low and stable between February and May of both years (Table 2), and increased until early July in 2007 but between late July and late September in 2006. The lowest glycogen value $\left(10.9 \pm 5.2 \mu \mathrm{g} \mathrm{mg}^{-1}\right.$ AFDW) was observed in late March 07 and the highest in late September $06\left(135.3 \pm 27.6 \mu \mathrm{g} \mathrm{mg}^{-1}\right.$ AFDW). After that, the glycogen content decreased until the end of the year. Glycogen was positively correlated (Spearman's $\mathrm{r}=0.71, \mathrm{P}<0.001$ ) with $\mathrm{CI}$ and total lipids (Spearman's $\mathrm{r}=0.54, \mathrm{P}=0.01$ ) and negatively correlated (Spearman's $\mathrm{r}=-0.65, \mathrm{P}<0.001)$ with the GI (Table 1). The lowest $\left(66.3 \pm 25.9 \mu \mathrm{g} \mathrm{mg}^{-1}\right.$ AFDW) and the highest $\left(156.4 \pm 17.3 \mu \mathrm{g} \mathrm{mg}^{-1}\right.$ AFDW) total lipid values were reached in early February 07 and early Decem- 
TABLE 2. - Mean values ( \pm sd) of shell length (mm), proteins, glycogen, total lipids ( $\mu \mathrm{g} \mathrm{mg}^{-1}$ AFDW) and total energy (kJ g ${ }^{-1}$ AFDW) of $V$. senegalensis during the experimental period (* statistically significant differences, $P<0.05$ found between consecutive months).

\begin{tabular}{|c|c|c|c|c|c|c|}
\hline Year & Month & $\begin{array}{l}\text { Shell Length } \\
(\mathrm{mm})\end{array}$ & $\begin{array}{c}\text { Protein } \\
\left(\mu \mathrm{gg}^{-1} \text { AFDW }\right)\end{array}$ & $\begin{array}{c}\text { Glycogen } \\
\left(\mu \mathrm{gg}^{-1} \text { AFDW }\right)\end{array}$ & $\begin{array}{c}\text { Total Lipids } \\
\left(\mu \mathrm{g} \mathrm{mg^{-1 }} \text { AFDW }\right)\end{array}$ & $\begin{array}{c}\text { Total energy } \\
\left(\mathrm{kJ} \mathrm{mg}^{-1} \text { AFDW }\right)\end{array}$ \\
\hline \multirow[t]{22}{*}{2006} & \multirow[t]{2}{*}{ Feb } & $36.5 \pm 0.9$ & $259.6 \pm 27.6$ & $20.8 \pm 4.4$ & $67.3 \pm 15.7$ & 7.2 \\
\hline & & -- & -- & -- & -- & -- \\
\hline & \multirow[t]{2}{*}{ Mar } & $35.5 \pm 0.7$ & $296.6 \pm 47.2$ & $16.4 \pm 3.0$ & $91.2 \pm 27.0$ & 8.6 \\
\hline & & $37.0 \pm 0.6$ & $324.7 \pm 45.2$ & $17.4 \pm 2.6$ & $103.3 \pm 25.5$ & 9.5 \\
\hline & \multirow[t]{2}{*}{ Apr } & $36.5 \pm 0.8$ & $235.5 \pm 88.2$ & $15.7 \pm 3.5$ & $125.4 \pm 17.9$ & 8.6 \\
\hline & & $37.8 \pm 0.9$ & $350.8 \pm 15.0$ & $18.2 \pm 4.4$ & $105.1 \pm 34.1$ & 10.1 \\
\hline & \multirow[t]{2}{*}{ May } & $37.3 \pm 1.0$ & $358.2 \pm 97.2$ & $21.9 \pm 9.5$ & $107.2 \pm 28.4$ & 10.3 \\
\hline & & $37.6 \pm 0.7$ & $142.2 \pm 48.8 *$ & $12.2 \pm 3.0$ & $86.3 \pm 25.0$ & 5.6 \\
\hline & \multirow[t]{2}{*}{ Jun } & $36.9 \pm 1.3$ & $175.7 \pm 33.3$ & $53.3 \pm 29.2$ & $117.2 \pm 14.3$ & 7.9 \\
\hline & & -- & -- & -- & -- & -- \\
\hline & \multirow{2}{*}{ Jul } & $36.2 \pm 0.4$ & $252.2 \pm 53.9$ & $37.3 \pm 21.6$ & $107.1 \pm 27.3$ & 8.7 \\
\hline & & $38.0 \pm 0.5$ & $250.7 \pm 49.0$ & $11.7 \pm 6.1$ & $104.1 \pm 35$ & 8.1 \\
\hline & \multirow[t]{2}{*}{ Aug } & $36.4 \pm 0.5$ & $216.2 \pm 37.2$ & $18.4 \pm 16.0$ & $110.6 \pm 21.3$ & 7.8 \\
\hline & & $36.8 \pm 0.9$ & $228.2 \pm 38.3$ & $32.5 \pm 21.3$ & $91.5 \pm 37.5$ & 7.7 \\
\hline & \multirow[t]{2}{*}{ Sep } & $37.5 \pm 1.5$ & $240.2 \pm 30.3$ & $107.9 \pm 23.6$ & $119.9 \pm 22.4$ & 10.1 \\
\hline & & $37.9 \pm 0.6$ & $246.9 \pm 16.3$ & $135.3 \pm 27.6$ & $136.1 \pm 30.2$ & 11.2 \\
\hline & \multirow[t]{2}{*}{ Oct } & $37.4 \pm 1.1$ & $237.0 \pm 74.5$ & $78.7 \pm 44.2$ & $100.0 \pm 13.0$ & 8.9 \\
\hline & & -- & -- & -- & -- & -- \\
\hline & \multirow{2}{*}{ Nov } & $36.9 \pm 1.0$ & $251.6 \pm 21.3$ & $83.7 \pm 14.5$ & $113.7 \pm 12.2$ & 9.7 \\
\hline & & $37.1 \pm 1.3$ & $274.2 \pm 25.6$ & $66.6 \pm 10.4$ & $146.4 \pm 18.1$ & 10.9 \\
\hline & \multirow[t]{2}{*}{ Dec } & $36.7 \pm 1.3$ & $354.5 \pm 30.0$ & $82.0 \pm 39.7$ & $156.4 \pm 17.3$ & 12.9 \\
\hline & & -- & -- & -- & $--\quad *$ & -- \\
\hline \multirow[t]{19}{*}{2007} & \multirow[t]{2}{*}{ Jan } & $36.9 \pm 1.1$ & $300.0 \pm 31.5$ & $42.5 \pm 22.8$ & $85.7 \pm 24.4$ & 8.9 \\
\hline & & $36.5 \pm 1.1$ & $377.3 \pm 112.6$ & $17.5 \pm 2.8$ & $77.2 \pm 3.7$ & 9.6 \\
\hline & \multirow[t]{2}{*}{ Feb } & $37.2 \pm 1.9$ & $225.5 \pm 36.0$ & $15.5 \pm 2.9$ & $66.3 \pm 25.9$ & 6.5 \\
\hline & & $37.3 \pm 1.7$ & $351.7 \pm 44.7$ & $38.2 \pm 30.1$ & $115.1 \pm 25.5$ & 10.8 \\
\hline & \multirow[t]{2}{*}{ Mar } & $36.4 \pm 0.4$ & $377.8 \pm 85.9$ & $19.8 \pm 5.0$ & $75.7 \pm 25.6$ & 9.6 \\
\hline & & $37.9 \pm 0.9$ & $273.2 \pm 38.7$ & $10.9 \pm 5.2$ & $92.4 \pm 30.4$ & 8.1 \\
\hline & \multirow[t]{2}{*}{ Apr } & $37.4 \pm 0.7$ & $243.1 \pm 61.0$ & $37.1 \pm 4.6$ & $115.6 \pm 25.0$ & 8.8 \\
\hline & & -- & -- & -- & -- & -- \\
\hline & \multirow[t]{2}{*}{ May } & $38.2 \pm 0.6$ & $248.6 \pm 67.1$ & $15.7 \pm 5.8$ & $78.1 \pm 20.0$ & 7.3 \\
\hline & & $36.4 \pm 1.4$ & $199.1 \pm 64.8$ & $25.8 \pm 7.6$ & $90.7 \pm 18.6$ & 7.0 \\
\hline & \multirow[t]{2}{*}{ Jun } & $38.2 \pm 0.7$ & $166.3 \pm 32.1$ & $33.7 \pm 16.6$ & $93.3 \pm 26.3$ & 6.6 \\
\hline & & -- & -- & -- & -- & -- \\
\hline & \multirow[t]{2}{*}{ Jul } & $38.7 \pm 0.3$ & $178.8 \pm 40.3$ & $98.3 \pm 48.4$ & $89.7 \pm 32.4$ & 7.9 \\
\hline & & $38.3 \pm 0.5$ & $280.1 \pm 12.2$ & $75.5 \pm 23.5$ & $99.3 \pm 18.5$ & 9.6 \\
\hline & \multirow[t]{2}{*}{ Aug } & $37.3 \pm 0.8$ & $202.9 \pm 55.9$ & $76.7 \pm 37$ & $109.2 \pm 32$ & 8.6 \\
\hline & & -- & -- & -- & -- & -- \\
\hline & \multirow{2}{*}{ Sep } & $37.7 \pm 0.3$ & $248.0 \pm 12.6$ & $28.2 \pm 16.8$ & $86.4 \pm 22.2$ & 7.8 \\
\hline & & $38.2 \pm 0.6$ & $248.6 \pm 34.1$ & $76.0 \pm 37.5$ & $130.5 \pm 44.1$ & 10.1 \\
\hline & Oct & $38.4 \pm 0.7$ & $215.8 \pm 41.8$ & $47.6 \pm 10.2$ & $136.0 \pm 35.6$ & 9.2 \\
\hline
\end{tabular}

ber 06 respectively (Table 2). Proteins and total lipids contributed most to the total energy content (proteins: Spearman's r=0.57, $\mathrm{P}<0.01$; total lipids: Spearman's $\mathrm{r}=0.53, \mathrm{P}=0.01)$ (Table 1). Statistically significant differences among sampling periods were observed for all the biochemical constituents (proteins: $\mathrm{K}-\mathrm{W}$., $\mathrm{H}=160.2$, d.f.=33, $\mathrm{P}<0.001$; glycogen: $\mathrm{K}-\mathrm{W}$., $\mathrm{H}=223.7$, d.f. $=33$, $\mathrm{P}<0.001$; total lipids: $\mathrm{K}-\mathrm{W} ., \mathrm{H}=133.6$, d.f. $=33, \mathrm{P}<0.001$; total energy: $\mathrm{K}-\mathrm{W}$., $\mathrm{H}=147.2$, d.f. $=33, \mathrm{P}<0.001)$. No significant differences were observed between years for proteins (K-W., $\mathrm{H}=1.0$ d.f. $=1, \mathrm{P}=0.306)$ and glycogen $(\mathrm{K}-\mathrm{W}, \mathrm{H}=0.04$, d.f. $=1, \mathrm{P}=0.843)$; however, total lipids (ANOVA $\mathrm{P}<0.001)$ and total energy $(\mathrm{K}-\mathrm{W}$, $\mathrm{H}=4.9$, d.f. $=1, \mathrm{P}<0.05)$ showed significant differences between 2006 and 2007.

\section{DISCUSSION}

The reproductive cycle of bivalves is controlled by the interaction between environmental and endogenous factors (Normand et al., 2008). In this study, gametogenesis of $V$. senegalensis was significantly influenced by water temperature, as has been previously reported for several other bivalve species (e.g. Gabbott, 1976; Xie and Burnell 1994; Albentosa et al., 2007). The seasonal SST pattern in Ria de Aveiro was characterized by relatively low temperatures during the winter that increased during early spring, stabilized in summer, and decreased in late autumn. The reproductive cycle of this species followed a seasonal cycle that correlated negatively with SST. It comprised a ripe stage in winter followed by an extended spawning period that began in late winter, was triggered by the rise of SST in spring and continued throughout the summer. A similar prolonged reproductive cycle was described by Villalba et al. (1993) for a population of V. senegalensis from Galicia (Spain) and for the Ria de Aveiro population by Maia et al. (2006). Moreover, CerviñoOtero et al. (2007a) observed ripe and spawning stages throughout the year for a population from the $\mathrm{O}$ Grove (SW of Galicia). Extended spawning seems to be an advantageous reproductive strategy for the species be- 
cause it ensures a continuous supply of settling larvae. Indeed, histological analyses showed gonias, maturing gametocytes and variable proportions of fully matured gametes simultaneously in the same individual. There was high intra-individual variation in gonadal maturation both in females and males. This phenomenon was reflected in the sequential development of gonadal stages, especially during the spawning period, when most of the population was "partially spawned" on a given sample date but had reinitiated gametogenesis on the following sample date (e.g. between late March and early April 06). Delgado and Pérez-Camacho (2007) also observed this great capacity for gonadal regeneration and the long reproductive period in Ruditapes philippinarum. Nevertheless, despite the intra-individual asynchrony, the synchronized gonadal development observed between males and females during this period is fundamental to the reproductive success of the species because sperm and oocytes are expelled into the water column simultaneously during the spawning period, which increases the probability of fertilization (O’Connor and Heasman, 1995). This synchronism was reported by Maia et al. (2006) in Ria de Aveiro but not by Villalba et al. (1993) in Galicia. The resting phases occurred during the summer, although total inactivity of the population was rare. The proliferation of gonias (early active stage) began during late summer/early autumn and gametogenesis intensified as the SST decreased in autumn. These results were generally consistent with the previous findings by Maia et al. (2006), although these authors reported the onset of gametogenesis in December. The results of the gonad index analyses of the present study reflect the relative variations in the gonads based on qualitative staging. A similar correlation was found for the white clam Spisula solida (Joaquim et al., 2008b).

The condition index was positively correlated with the SST and inversely correlated with reproductive activity. The CI showed a seasonal cycle: it decreased during gametogenesis but increased again even during the spawning period. This pattern indicates that there is rapid recovery followed by an accumulation of reserves in summer during the resting phase. These reserves are then used in the next gametogenic cycle. The CI reached its maximum value in September 06 and October 07 at the beginning of gametogenesis. The relationship between CI and the reproductive cycle has been observed in several other bivalve species from the Portuguese coast (Gaspar and Monteiro, 1998; Moura et al., 2008). However, in the present work, the negative relationship between the CI and GI may not be a direct consequence of the reproductive cycle of the species, but rather a consequence of the energy storage and exploitation strategy. Joaquim et al. (2008b) found that the CI for Spisula solida is highly influenced by the energy storage pattern. Similarly, Delgado and Pérez-Camacho (2005) reported that the evolution of the dry soft-tissue weight in $R$. decussatus indicates the energy status of the organism and the volume of gonad produced. Several studies on bivalves have shown that gametogenesis is associated with an annual cycle of the accumulation and use of energy reserves, which is influenced by environmental parameters such as food availability and temperature (Fernandez Castro and Vido de Mattio, 1987; Massapina et al., 1999; Pérez-Camacho et al., 2003). Generally, energy is accumulated when food is abundant, and this energy is then used to synthesize gametes, which are liberated during the spawning process. This cycle translates into a seasonal pattern of biochemical composition that can vary among populations and species (Albentosa et al., 2007). The relative amounts of protein (142 to $378 \mu \mathrm{g} \mathrm{mg}^{-1}$ AFDW), glycogen (11 to $146 \mu \mathrm{g} \mathrm{mg}^{-1}$ AFDW) and total lipids (66 to $156 \mu \mathrm{g} \mathrm{mg}^{-1}$ AFDW) measured in $V$. senegalensis were similar to those previously described in the literature for this species (AlvarezSeoane, 1960; Cerviño-Otero et al., 2007b).

Many authors have suggested that somatic protein is used as an energy reserve during gametogenesis in bivalves (Gabbott and Bayne, 1973; Liu et al., 2008), including in V. senegalensis (Albentosa et al., 2007; Cerviño-Otero et al., 2007b). In this study, although protein was negatively correlated with SST and CI, the relationship between protein and GI was not significant. Similar results were observed for the Pacific oyster Crassostrea gigas $(\mathrm{Li}$ et al., 2009). Moreover, the lack of a significant correlation between proteins and glycogen suggests that proteins are not generally used as an energy source for maintenance when carbohydrate reserves have been depleted; this is contrary to what González (1975) found for this species previously as well as the findings for other bivalves (Barber and Blake, 1981; Pérez-Camacho et al., 2003; Joaquim et al., $2008 b)$. Nevertheless, the protein concentration followed the sudden decrease in the GI in May 06 and February 07, which suggests that in a stressful situation of energy imbalance provoked by the extended breeding period of the species, which includes simultaneous spawning effort and development of new gonias and maturing gametocytes, this species can use proteins as an energy reserve. Mao et al. (2006) reported excessive use of protein during and after the spawning period in $C$. gigas. According to Albentosa et al. (2007), in response to a starvation situation, females of $V$. senegalensis obtained most of their energy to maintain vital functions from the catabolism of proteins and in males this energy was obtained from the catabolism of proteins and lipids in equal proportions.

Glycogen is the main energy reserve in adult bivalves. It can be an energy source for growth and at the same time stored in specific cells as an energy reserve during the vitellogenic process (Marin et al., 2003). V. senegalensis accumulates glycogen in summer, before the intensification of the gametogenesis 
process that will take place in autumn/early winter, and uses it during spawning in late winter, spring and early summer, when this energy reserve will be totally depleted. This glycogen pattern was also observed for this species by Pérez-Camacho (1980) and for other typical conservative species such as $A$. irradians concentratus (Barber and Blake, 1981), Argopecten purpuratus (Martinez, 1991) and Ruditapes decussatus (Ojea et al., 2004), since gametogenesis depends largely on the amount of glycogen stored. Indeed, this biochemical compound was correlated positively with CI and negatively with GI.

Several authors (e.g. Beninger and Lucas, 1984; Ojea et al., 2004; Mouneyrac et al., 2008) have reported a negative relationship between glycogen and lipids, probably due to the conversion of glycogen to lipids biosynthesized during the formation of gametes (Gabbott, 1975). In the present study, although there was a significant increase in lipids during autumn when an intensification of the gametogenesis process with glycogen losses occurs, there was generally positive synchronism between these two parameters. Therefore, contrary to the pattern usually reported for the majority of bivalves, in this study a positive relationship was observed between total lipids and glycogen. These results suggest that, more than a consequence of gametogenesis in autumn/winter, total lipid behaviour reflects the energy accumulation process. $V$. senegalensis accumulates both total lipids and carbohydrates during the early stages of gametogenesis. Lipids are depleted following spawning due to the gametes being expelled. The rapid decline in lipid content observed in January 07 during the gametogenesic process, may be explained by nutritional stress and energy imbalances during this period of low SST. The scarcity of food may also explain these results. In fact, Albentosa et al. (2007) reported that in $V$. senegalensis lipids contribute more than carbohydrates to the energy demands for sustaining vital functions during starvation periods. Although we have no data on the food availability in Ria de Aveiro for this year, some studies reported minimum values of chlorophyll a in January (Lopes and Silva, 2006; Lopes et al., 2007). This behaviour of total lipids may explain why there is no correlation between this parameter and the GI. Fernandez Castro and Vido de Mattio (1987) observed similar lipid and glycogen response cycles in Ostrea puelchana.

This study shows that in $V$. senegalensis, proteins and total lipids contribute significantly to the total energy supply, since they were all positively correlated. During the spawning period the energy balance was stabilized mainly by proteins, whereas during the gametogenesis process, the total lipids reinforced the total energy reserves. In summer, when food is abundant, a surplus of energy is available to be used for gonad and somatic development, as has previously been suggested by Ojea et al. (2004) for $R$. decussatus.
In conclusion, the results of this study show that $V$. senegalensis is a conservative species, since gametogenesis takes place in autumn/early winter at the expense of reserves accumulated previously in late summer during a short period of time. Moreover, this species has a prolonged spawning period that starts in winter and ends in the middle of summer.

Besides the genetic plasticity and genetic similarity of the two populations reported by Joaquim et al.(2010), and which make the Ria de Aveiro $V$. senegalensis population a genetically viable broodstock for intensive hatchery production of juveniles, the extended spawning period of this $V$. senegalensis population has interesting implications for the implementation of profitable aquaculture. This extended natural spawning period implies that manipulation of broodstock in terms of conditioning, which should be initiated in late summer, would be relatively easy. Moreover, this species' great capacity for gonadal regeneration, coupled with its high gonadal development rate would provide larvae over much of the year without extensive and expensive broodstock conditioning. Information on the gametogenic and spawning periods and consequent energy storage can also provide the optimal reproductive time for artificial spawning induction in aquaculture. The results of this study can be used to adjust fishing effort by modifying management regulations, and also in aquaculture production to restore the Ria de Aveiro population and rebuild the depleted Ria Formosa population.

\section{ACKNOWLEDGEMENTS}

The authors would like to acknowledge the staff of Molluscan Aquaculture Experimental Station in Tavira, and Vitor Bettencourt of IPIMAR Aveiro for collecting the samples. Special thanks are also due to Dr. Alexandra Leitão whose suggestions greatly improved this manuscript. The authors are also grateful to Dr. Montserrat Ramón (Editor of Scientia Marina) and two anonymous referees, whose valuable comments and suggestions greatly improved the revised version of the manuscript. This study was partially funded by the PROMAR Project (Interreg IIIA).

\section{REFERENCES}

Albentosa, M., M.J. Fernández-Reiriz, U. Labarta, and A. PérezCamacho. - 2007. Response of two species of clams, Ruditapes decussatus and Venerupis pullastra, to starvation: Physiological and biochemical parameters. Comp. Biochem. Phys., 146: 241-249.

Alvarez-Seoane, G. - 1960. Variación estacional de la composición química de la almeja babosa (Tapes pullastra, Mont.). Inv. Pesq., 17: 2-32.

Barber, B.J. and N.J. Blake. - 1981. Energy storage and utilization in relation to gametogenesis in Argopecten irradians concentricus (Say). J. Exp. Mar. Biol. Ecol., 52: 121-134.

Beninger, P.G. and A. Lucas. - 1984. Seasonal variation in condition, reproductive activity and gross biochemical composition of two species of adult clam reared in a common habitat: Tapes 
decussatus L. (Jeffreys) and Tapes philippinarum (Adams and Reeve). J. Exp. Mar. Biol. Ecol., 79: 19-37.

Beukema, J.J. and W. De Bruin. - 1979. Calorific values of the soft parts of the tellinid bivalve Macoma balthica (L.) as determined by two methods. J. Exp. Mar. Biol. Ecol., 37: 19-30.

Cerviño-Otero, A., J. Ojea, S. Nóvoa and D. Martínez. - 2007a. Comparativa de la evolución del Ciclo Gametogénico entre una población submareal y otra intermareal de almeja babosa Venerupis pullastra (Montagu, 1803) de O Grove (SO de Galicia). Act. XI Congr. Nac. Acuic., 427-430.

Cerviño-Otero, A., S. Nóvoa, J. Ojea and D. Martínez. - 2007b. Composición bioquímica de dos poblaciones naturales de almeja babosa Venerupis pullastra (Montagu, 1803) de O Grove (SO de Galicia). Diferencias entre el intermareal y submareal. Act. XI Congr. Nac. Acuic., 431-434.

Delgado, M. and A. Pérez-Camacho. - 2005. Histological study of the gonadal development of Ruditapes decussatus (L.) (Mollusca: Bivalvia) and its relationship with available food. Sci. Mar., 69: 87-97.

Delgado, M. and A. Pérez-Camacho. - 2007. Comparative study of gonadal development of Ruditaes philippinarum (Adams and Reeve) and Ruditapes decussatus (L.) (Mollusca: Bivalvia): Influence of temperature. Sci. Mar., 71(3): 471-484.

FAO. - 2006-2010. Cultured Aquatic Species Information Programme. Venerupis pullastra. Text by Figueras, A. In: FAO Fisheries and Aquaculture Department [online]. Rome. Updated 26 October 2006. http://www.fao.org/fishery/culturedspecies/ Venerupis_pullastra/en

Fernandez Castro, N. and N. Vido de Mattio. - 1987. Biochemical composition, condition index, and energy value of Ostrea puelchana (d'Orbigny): relationships with reproductive cycle. J. Exp. Mar. Biol. Ecol., 108: 113-126.

Folch, J., M. Lees and G.H. Sloane Stanley. - 1957. A simple method for the isolation and purification of total lipids from animal tissue. J. Biol. Chem., 226: 497-509.

Gabbott, P.A. - 1975. Storage cycles in marine bivalve molluscs: a hypothesis concerning the relationship between glycogen metabolism and gametogenesis. In: H. Barnes (eds.), Proc. 9th Eur. Mar. Biol. Symp. Aberdeen University Press, Aberdeen: 191-211.

Gabbott, P.A. - 1976. Energy metabolism. In: B.L. Bayne (eds.), Marine Mussels:Their Ecology and Physiology. Cambridge University Press: 293-357.

Gabbott, P.A. and B.L. Bayne. - 1973. Biochemical effects of temperature and nutritive stress on Mytilus edulis L. J. Mar. Biol. Assoc. U.K., 53: 269-286.

Gaspar, M.B. and C.C. Monteiro. - 1998. Reproductive cycles of the razor clam Ensis siliqua and the clam Venus striatula off Vilamoura, southern Portugal. J. Mar. Biol. Assoc. U.K., 78: $1247-1258$.

González, N. - 1975. Composición bioquímica y medio ambiente de Venerupis decussata y Venerupis pullastra en la ría de Pasaje, La Coruña. Bol Inst. Esp. Oceanogr., 194: 3-44.

Joaquim, S., M.B. Gaspar, D. Matias, R. Ben-Hamadou and W.S. Arnold. - 2008a. Rebuilding viable spawner patches of the overfished Spisula solida (Mollusca: Bivalvia): a preliminary contribution to fishery sustainability. ICES J. Mar. Sci., 65: 60-64.

Joaquim, S., D. Matias, B. Lopes, W.S. Arnold and M.B. Gaspar. -2008 b. The reproductive cycle of white clam Spisula solida (L.) (Mollusca: Bivalvia): Implications for aquaculture and wild stock management. Aquaculture, 281: 43-48.

Joaquim, S., J. Pereira, A. Leitão, D. Matias, R. Chaves, H. GuedesPinto, L. Chícharo and M.B. Gaspar. - 2010. Genetic diversity of two Portuguese populations of the pullet carpet shell Venerupis senegalensis, based on RAPD markers: Contribution to a sustainable restocking program. Helgol. Mar. Res., DOI 10.1007/s10152-009-0182-7.

Li, Y., J.G. Qin, X. Li and K. Benkendorff. - 2009. Monthly variation of condition index, energy reserves and antibacterial activity in Pacific oysters, Crassostrea gigas, in Stansbury (South Australia). Aquaculture, 286: 64-71.

Liu, W., Q. Li, Y. Yuan and S. Zhang. - 2008. Seasonal variations on reproductive activity and biochemical composition of the cockle Fulvia mutica (Reeve) from the eastern coast of China. J. Shellfish Res., 27 (2): 405-411.

Lopes, J.F. and C. Silva. - 2006. Temporal and spatial distribution of dissolved oxygen in the Ria de Aveiro lagoon. Ecol. Model., 197: 67-88.

Lopes, C.B., A.I. Lillebø, J.M. Dias, E. Pereira, C. Vale and A.C. Duarte. - 2007. Nutrient dynamics and seasonal succession of phytoplankton assemblages in a Southern European Estuary: Ria de Aveiro, Portugal. Est. Coast. Shelf Sci., 71: 480-490.

Magnesen, T. and G. Christophersen.- 2008. Reproduction cycle and conditioning of translocated scallops (Pecten maximus) from five broodstock populations in Norway. Aquaculture, 285: 109-116.

Maia, F., M.P. Sobral and M.B. Gaspar. - 2006. Ciclo reprodutivo e primeira maturação de Solen marginatus e Venerupis pullastra na Ria de Aveiro. Bases científicas para a gestão destes recursos. Relat. Cient. Téc. IPIMAR, 30: 1-35.

Mao, Y., Y. Zhou, H. Yang and R.Wang. - 2006. Seasonal variation in metabolism of cultured Pacific oyster, Crassostrea gigas, in Sanggou Bay, China. Aquaculture, 253: 322-333.

Marin, M.G., V. Moschino, M. Deppieri and L. Lucchetta. - 2003. Variations in gross biochemical composition, energy value and condition index of $T$. philippinarum from the lagoon of Venice. Aquaculture, 219: 859-871.

Marsh, J.B. and D.B. Weinstein. - 1966. Simple charring method for determination of lipids. J. Lipid Res., 7: 574-576.

Martinez, G. - 1991. Seasonal variation in biochemical composition of three size classes of Chilean scallop Argopecten purpuratus Lamarck, 1819. Veliger, 34: 335-343.

Massapina, C. and I. Arrobas. - 1991. A cultura de moluscos bivalves na Ria Formosa: estado actual e perspectivas. $1^{\circ}$ Simpósio NOPROT, 4-6 Abril, Abstract book: 22-23.

Massapina, C., S. Joaquim, D. Matias and N. Devauchelle. - 1999. Oocyte and embryo quality in Crassostrea gigas (Portuguese strain) during a spawning period in Algarve, South Portugal. Aquat. Living Resour., 12: 327-333.

Mathieu, M., and P. Lubet. - 1993. Storage tissue metabolism and reproduction in marine bivalves - a brief review. Invertebr. Reprod. Dev., 23: 123-129.

Mouneyrac, C., S. Linot, J.-C. Amiard, C. Amiard-Triquet, I. Métais, C. Durou, C. Minier, and J. Pellerin. - 2008. Biological indices, energy reserves, steroid hormones and sexual maturity in the infaunal bivalve Scrobicularia plana from three sites differing by their level of contamination. Gen., Comp. Endocrinol., 157: 133-141.

Moura, P., M.B. Gaspar and C.C. Monteiro. - 2008. Gametogenic cycle of the smooth clam Callista chione on the southwestern coast of Portugal. J. Mar. Biol. Assoc. U.K., 88: 161-167.

Normand, J., M. Le Pennec and P. Boudry. - 2008. Comparative histological study of gametogenesis in diploid and triploid $\mathrm{Pa}$ cific oysters (Crassostrea gigas) reared in an estuarine farming site in France during the 2003 heatwave. Aquaculture, 282: 124-129.

O'Connor, W.A. and M.P. Heasman. - 1995. Spawning induction and fertilisation in the doughboy scallop Chlamys (Mimachlamys) asperrima. Aquaculture, 136: 117-129.

Ojea, J., A.J. Pazos, D. Martinez, S. Novoa, J.L. Sanchez and M. Abad. - 2004. Seasonal variation in weight and biochemical composition of the tissues of Ruditapes decussatus in relation to the gametogenic cycle. Aquaculture, 238: 451-468.

Paine, R.T. - 1971. The measurement and application of the calorie to ecological problems. Ann. Rev. Ecolog. Syst., 2: 145-164.

Pérez-Camacho, A. - 1980. Biología de Venerupis pullasta (Montagu, 1983) y Venerupis decussata (Linne, 1767), con especial referencia a los factores determinantes de la producción. Bol. Inst. Esp. Oceanogr., 5(4): 43-76.

Pérez-Camacho, A., M. Delgado, M.J. Fernández-Reiriz and U. Labarta. - 2003. Energy balance, gonad development and biochemical composition in the clam Ruditapes decussatus. Mar. Ecol. Prog. Ser., 258: 133-145.

Shakir, F.K., D. Audilet, A.J. Drake III and M.M. Shakir. - 1994. A rapid protein determination by modification of the Lowry Procedure. Anal. Biochem., 216: 232-233.

Seed, R. - 1976. Ecology. In B.L, Bayne (eds.), Marine mussels: Their ecology and Physiology, Cambridge University Press: 13-65.

Sokal, R.R. and F.J. Rohlf. - 1981. Biometry. W.H. Freeman Co. (eds.), San Francisco.

Viles, F.J. and Silverman. - 1949. Determination of starch and cellulose with anthrone. J. Anal. Chem., 21: 950-953. 
Villalba, A., M.J. Carballal and M. C. López. - 1993. Estudio del ciclo gonadal de tres especies de almeja, Ruditapes decussatus, Venerupis pullastra y Venerupis romboides de la rías gallegas. Act. IV Congr. Nac. Acuic..: 341-346.

Walne, P.R. and R. Mann. - 1975. Growth and biochemical composition of Ostrea edulis and Crassostrea gigas. In: H. Barnes (eds.), Proc. 9th Eur. Mar. Biol. Symp. Oban. Scotlland. 587-607.
Xie, Q. and G.M. Burnell. - 1994. A comparative study of the gametogenic cycles of the clams Tapes philippinarum (Adams and Reeve 1850) and Tapes decussatus (Linnaeus) on the south coast of Ireland. J. Shellfish Res., 13 (2): 467-472.

Scient. ed.: M. Ramón.

Received September 1, 2009. Accepted July 30, 2010.

Published online March 8, 2011. 